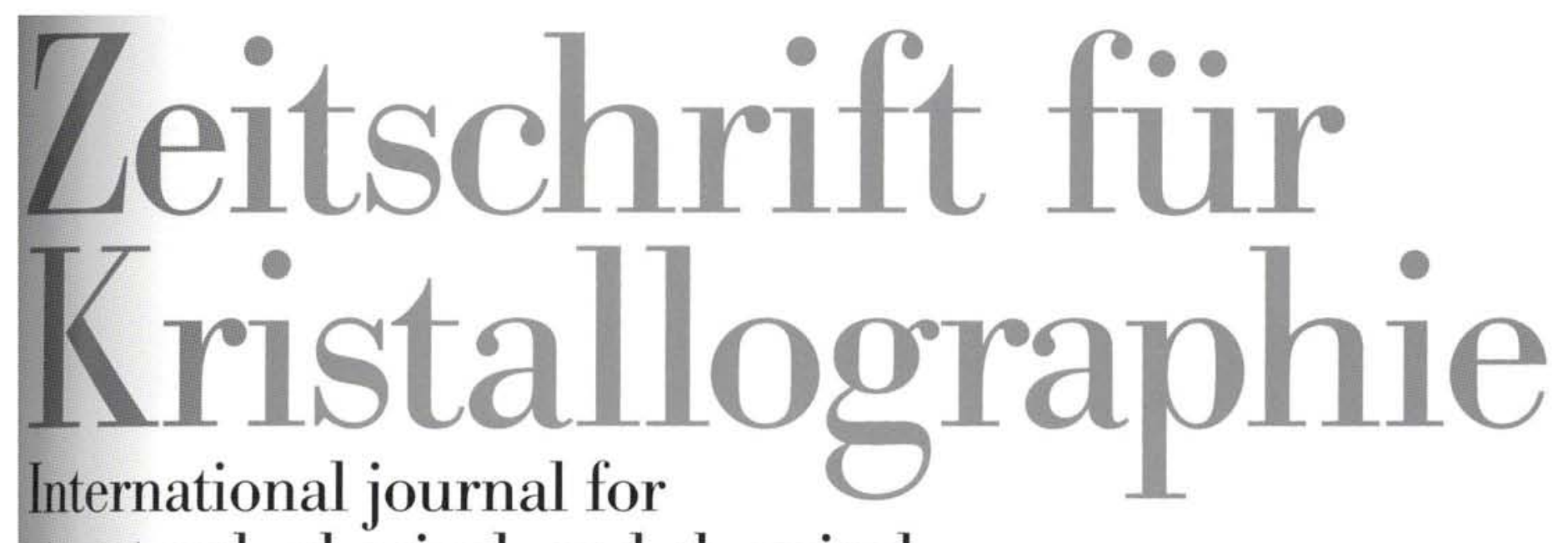
structural, physical, and chemical aspects of crystalline materials
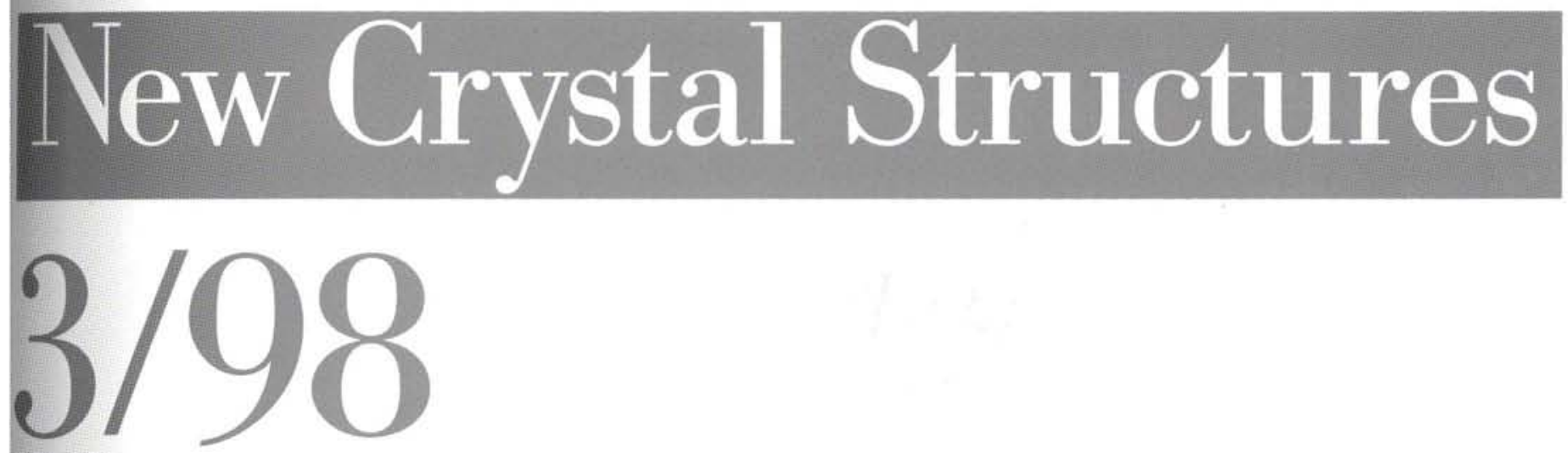

Volume 213 


\section{Zeitschrift für Kristallographie - New Crystal Structures}

International journa for structural, physical, and chemical aspects of crystalline materials

Zeitschrift für Krisallographie - New Crystal Structures offers a place for researchers to present

(i) results of deteminations of hitherto unknown crystal structures which do not justify detailed discussion of determination procedure, crystal structure, and/or structure-property relations (routine determinations and structures),

(ii) refinement of previously published crystal structures which do not require a new description or discussion.

New Crystal Strucures (NCS) have to be electronically submitted to the publisher:

\section{R. Oldenbourg Verlag \\ Lektorat $\mathrm{M} / \mathrm{N}$ \\ K. Berber-Nerlinger \\ Postfach 801360 \\ D-81613 München \\ Tel.: 49/89/4 $5051-324$ \\ Telefax: 49/89/4 5051-2 04 \\ e-mail: zkrist@vertag.oldenbourg.de \\ www: http://www.oldenbourg.de/mn/mn-nes1.htm}

\section{Editor in chief:}

Prof. H. Schulz.

\section{Managing Editor:}

Dr. Yu. Grin.

Fax: +49-7 11-6 89-1010

e-mail: grin@vsibml.mpi-stuttgart.mpg.de

(Addresses are primed on the inside cover page.)

For detailed information please see the Instructions to Contributors. Thes are printed in Issue 1 and 3 of each Volume and can also be obtained as reprints from $\mathbf{R}$. Oldenbourg Verlag. They can be called from the ftp-server: ftp://ftp.oldenbourg.de/pub/zkrist
C Copyright 1998 by R. Oldenbourg Verlag GmbH, D-81671 München.

All rights reserved (including translation and storage by electronic means). No part of this issue may be reproduced in any form - by photoprint, microfilm, or any other means - nor transmitted or translated into a machine language without written permission from the publisher.

The journal has been registered with the Copyright Clearance Center (CCC), 27 Congress Street, Salem, MA 01970, U.S.A., under the fee code 1433-7266. Registered names, trademarks, etc. used in this journal, even when not marked as such, are not to be considered unprotected by law.

\section{Z. Kristallogr. 213 (1998) \\ ISSN 1433-7266 \\ R. Oldenbourg Verlag, München}

\section{Subscription information}

Volume 213: 4 issues will appear in 1998

Annual subscription prices: DM 358,-/öS 2613,-/SFR $308,-$ + postage: DM 36,- (Germany), DM 50,-/öS 365,-/ SFR 43,- (elsewhere).

Single issue: DM 96,-/öS 701,-/SFR 83,- + postage.

For EU countries all prices are including 7\% VAT, for all other countries they are gross prices.

Orders can either be placed with your bookdealer or sent directly to the publisher.

\section{Cancellation of subscription}

The publisher must be notified not later than three months before the end of the calendar year.

\section{Setting and printing}

Druckhaus „Thomas Müntzer“ GmbH, Bad Langensalza 